\title{
Nautilia lithotrophica gen. nov., sp. nov., a thermophilic sulfur-reducing $\varepsilon$-proteobacterium isolated from a deep-sea hydrothermal vent
}

\author{
1 Institute of Microbiology, \\ Russian Academy of \\ Sciences, Prospect 60-letiya \\ Oktyabrya 7/2, 117811 \\ Moscow, Russia \\ 2 UMR 6539, Centre National \\ de la Recherche \\ Scientifique et Université \\ de Bretagne Occidentale, \\ Institut Universitaire \\ Européen de la Mer, 29280 \\ Plouzané, France \\ ${ }^{3}$ DSMZ - German Collection \\ of Microorganisms and Cell \\ Cultures, Mascheroder \\ Weg 1b, 38124 \\ Braunschweig, Germany
}

\author{
M. L. Miroshnichenko, ${ }^{1}$ N. A. Kostrikina, ${ }^{1}$ S. L'Haridon, ${ }^{2}$ C. Jeanthon, ${ }^{2}$ \\ H. Hippe, ${ }^{3}$ E. Stackebrandt ${ }^{3}$ and E. A. Bonch-Osmolovskaya ${ }^{1}$
}

Author for correspondence: M. L. Miroshnichenko. Tel: +7 09513544 58. Fax: +7 0951356530. e-mail: mir@inmi.host.ru

\begin{abstract}
A novel, strictly anaerobic, thermophilic sulfur-reducing bacterium, strain $525^{\top}$, was isolated from tubes of the deep-sea hydrothermal vent polychaete Alvinella pompejana, collected on the East Pacific Rise $\left(13^{\circ} \mathrm{N}\right)$. This organism grew in the temperature range $37-68^{\circ} \mathrm{C}$, the optimum being $53^{\circ} \mathrm{C}$, and in the pH range 6.4-7.4, the optimum being 6.8-7.0. The $\mathrm{NaCl}$ range for growth was 0.8-5.0\%, the optimum being 3.0\%. Strain $525^{\top}$ grew lithoautotrophically with $\mathrm{H}_{2}$ as energy source, $\mathrm{S}^{0}$ as electron acceptor and $\mathrm{CO}_{2}$ as carbon source.
\end{abstract}

Alternatively, strain $525^{\top}$ was able to use formate as an energy source. The $\mathbf{G}+\mathrm{C}$ content of the genomic DNA was $34.7 \mathrm{~mol} \%$. Phylogenetic analysis of the $16 \mathrm{~S}$ rDNA gene sequence placed strain $5^{2} 5^{\mathrm{T}}$ in the $\varepsilon$-subclass of the Proteobacteria, where it forms a deep cluster with recently isolated relatives. On the basis of phenotypic and phylogenetic differences between strain $525^{\top}$ and its closest phylogenetic relatives, it is proposed that the new isolate should be described as a member of a new genus, Nautilia, for which the name Nautilia lithotrophica gen. nov., sp. nov. is proposed. The type strain is strain $5_{25}^{\top}$ (= DSM 13520').

Keywords: deep-sea hot vents, sulfur reduction, thermophile, lithotroph, epsilonProteobacteria

\section{INTRODUCTION}

Deep-sea hydrothermal vents represent a unique microbial habitat characterized by extreme temperature gradients and high concentrations of hydrogen sulfide, gases and toxic heavy metals. The vents are colonized by highly specific invertebrate fauna, the growth of which is supported by symbiotic and non-symbiotic chemosynthetic micro-organisms (Jannasch \& Mottle, 1985).

Alvinella pompejana is a tube-dwelling annelid polychaete endemic to the East Pacific Rise; it inhabits the hot areas of active deep-sea hydrothermal vent chimneys. One of the most striking features of this worm is its obligate association with a highly diverse and dense assemblage of epibiotic micro-organisms. Dorsal epidermal expansions are covered by fila-

Published online ahead of print on 18 February 2002 as DOI 10.1099/ijs.0.02139-0.

The GenBank accession number for the $16 \mathrm{~S}$ rDNA sequence of strain $525^{\top}$ is AJ404370. mentous morphotypes that dominate the wormbacteria association. To date, these dominant morphotypes have eluded all attempts at culture. However, molecular methods have identified constant features of the associated microflora as being those of representatives of the $\varepsilon$-subclass of the Proteobacteria (Haddad et al., 1995; Cary et al., 1997). Very recently, four thermophilic e-Proteobacteria associated with the worm's epidermis, but phylogenetically distant from its epibionts, were isolated and characterized (Campbell et al., 2001). In this study, we report the isolation, from tube fragments of $A$. pompejana, of a closely related organism and propose that it represents the type species of a new genus.

\section{METHODS}

Sampling. The new strain was isolated from tube fragments of an $A$. pompejana specimen sampled at the $13^{\circ} \mathrm{N}$ hydrothermal vent field $\left(12^{\circ} 48^{\prime} \mathrm{N}, 103^{\circ} 56^{\prime} \mathrm{W}\right)$, during the Amistad cruise (in 1999), on the East Pacific Rise at a depth of $2600 \mathrm{~m}$

Enrichment and isolation. For the enrichment of thermo- 
philic sulfur-reducing bacteria, the following basal medium was used: $\mathrm{NH}_{4} \mathrm{Cl}, 0.33 \mathrm{~g} \mathrm{l}^{-1} ; \mathrm{KCl}, 0.33 \mathrm{~g} \mathrm{l}^{-1} ; \mathrm{KH}_{2} \mathrm{PO}_{4}$, $0.33 \mathrm{~g} \mathrm{l}^{-1} ; \mathrm{CaCl}_{2} .2 \mathrm{H}_{2} \mathrm{O}, 0.33 \mathrm{~g} \mathrm{l}^{-1} ; \mathrm{MgCl}_{2} \cdot 6 \mathrm{H}_{2} \mathrm{O}, 0.33 \mathrm{~g} \mathrm{l}^{-1}$; $\mathrm{NaCl}, 25 \cdot 0 \mathrm{~g} \mathrm{l}^{-1}$; yeast extract, $0 \cdot 1 ; \mathrm{Na}_{2} \mathrm{~S} .9 \mathrm{H}_{2} \mathrm{O}, 0.5 \mathrm{~g} \mathrm{l}^{-1}$; $\mathrm{NaHCO}_{3}, 0.5 \mathrm{~g} \mathrm{l}^{-1}$; resazurin, $0.002 \mathrm{~g} \mathrm{l}^{-1}$; trace elements (Balch et al., 1979), $1 \mathrm{ml} \mathrm{1}^{-1}$; vitamins (Wolin et al., 1963), $1 \mathrm{ml} \mathrm{l}^{-1}$. The medium was prepared anaerobically (Balch et al., 1979) and dispensed in $15 \mathrm{ml}$ Hungate tubes, the headspaces $\left(10 \mathrm{ml}\right.$ ) being filled with an $\mathrm{H}_{2} / \mathrm{CO}_{2}$ mixture (8: $2, \mathrm{v} / \mathrm{v}$; atmospheric pressure). Elemental sulfur was added as a sulfur flower aqueous suspension to a final concentration of $10 \mathrm{~g} \mathrm{l}^{-1}$. The $\mathrm{pH}$ of the medium was adjusted with $2.5 \mathrm{M}$ $\mathrm{H}_{2} \mathrm{SO}_{4}$ or with $5 \mathrm{M} \mathrm{NaOH}$ to $6 \cdot 8-7 \cdot 0$. When substrates other than molecular hydrogen were tested, the headspaces were filled with $\mathrm{N}_{2} / \mathrm{CO}_{2}(8: 2, \mathrm{v} / \mathrm{v}$; atmospheric pressure). Colonies were obtained on the same basal medium with $0.3 \%$ formate and without yeast extract, solidified by $1.5 \%$ agar (Difco). In this case, sulfur was substituted by polysulfides (Widdel \& Pfennig, 1992). Agar shake tubes were incubated at $55^{\circ} \mathrm{C}$ for $3-5$ days.

Morphological and ultrastructural studies. The morphology of the new isolate was examined using a light microscope (Mikmed-1; LOMO). The ultrastructure of the whole cells and thin sections was studied as described by BonchOsmolovskaya et al. (1990).

Physiological studies. Potential growth substrates and electron acceptors were added at concentrations of 0.3 and $0.2 \%$ $(\mathrm{w} / \mathrm{v})$, respectively. Tests for growth with ferric iron as an electron acceptor were performed in sulfide-free medium with $90 \mathrm{mM}$ amorphous ferric oxide replacing the elemental sulfur. For carbon-source examination, the headspace was filled with $100 \% \mathrm{H}_{2}$ (atmospheric pressure), and $\mathrm{NaHCO}_{3}$ was omitted from the medium. The concentration of each possible carbon source was $0.05 \%$. When possible nitrogen sources were tested, $\mathrm{NH}_{4} \mathrm{Cl}$ in the medium was replaced by $\mathrm{NaNO}_{3}$, glutamate, yeast extract, gelatin, tryptone and urea (final concentration $0 \cdot 04 \%$ ). Inoculated tubes were incubated at $55^{\circ} \mathrm{C}$. Bacterial growth was followed by examining the turbidity, and checked by visualization under a light microscope and by measurement of the hydrogen sulfide concentration in the medium.

Analytical methods. The cell density was determined by direct cell counting using a light microscope. Gaseous and liquid fermentation products were detected by means of gas-liquid chromatography (Miroshnichenko et al., 1994). Hydrogen sulfide was measured by a colorimetric method (Trüper \& Schlegel, 1964). All experiments were done in triplicate. Determination of the $\mathrm{G}+\mathrm{C}$ content of the DNA was performed using the HPLC method of Mesbah et al. (1989), using conditions as described by Labrenz et al. (2000).

Antibiotic susceptibility. The sensitivity of strain $525^{\mathrm{T}}$ to rifampicin, chloramphenicol, vancomycin, penicillin and streptomycin (at final concentrations of 10, 25, 50 and $100 \mu \mathrm{g} \mathrm{ml}^{-1}$, respectively) was tested at $55^{\circ} \mathrm{C}$.

$16 \mathrm{~S}$ rDNA-based phylogenetic analysis. Extraction of genomic DNA, PCR-mediated amplification of the 16S rDNA and direct sequencing of the purified PCR product were carried out according to Rainey et al. (1996). The 16S rDNA was assembled from overlapping PCR fragments obtained in the forward and reverse directions. About $70 \%$ of DNA was double-stranded and $30 \%$ single-stranded. The sequence reaction mixtures were electrophoresed using a model 373A automatic DNA sequencer (Applied Biosystems). The 16S rDNA sequences were aligned with published sequences obtained from the EMBL Nucleotide
Sequence Database (Cambridge) and the Ribosomal Database Project (RDP) using the ae2 editor (Maidak et al., 1996). Evolutionary distances were calculated by the methods of De Soete (1983), Jukes \& Cantor (1969) and Felsenstein (1993), and included neighbour-joining and maximum-likelihood and consensus analyses. Bootstrap analysis was used to evaluate the tree topology of the neighbour-joining data by performing 500 resamplings (Felsenstein, 1993).

\section{RESULTS}

\section{Enrichments and isolation}

Anaerobic medium with $\mathrm{H}_{2}$ serving as an electron donor and elemental sulfur as an electron acceptor was inoculated with tube fragments of $A$. pompejana and incubated at $55^{\circ} \mathrm{C}$. After 3 days incubation, an intense growth of morphologically diverse micro-organisms
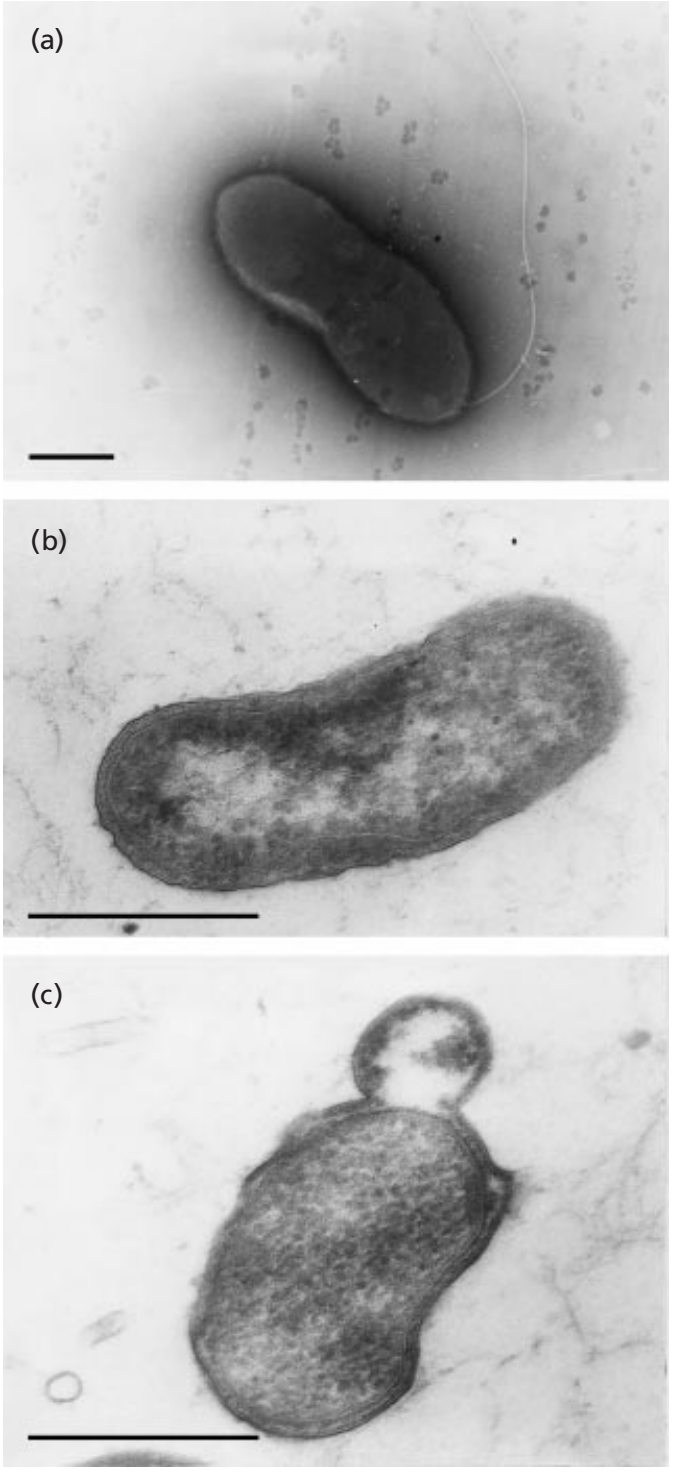

Fig. 1. Negatively stained whole cells (a) and thin sections (b, c) of strain $525^{\top}$. Bars, $0.5 \mu \mathrm{m}$. 


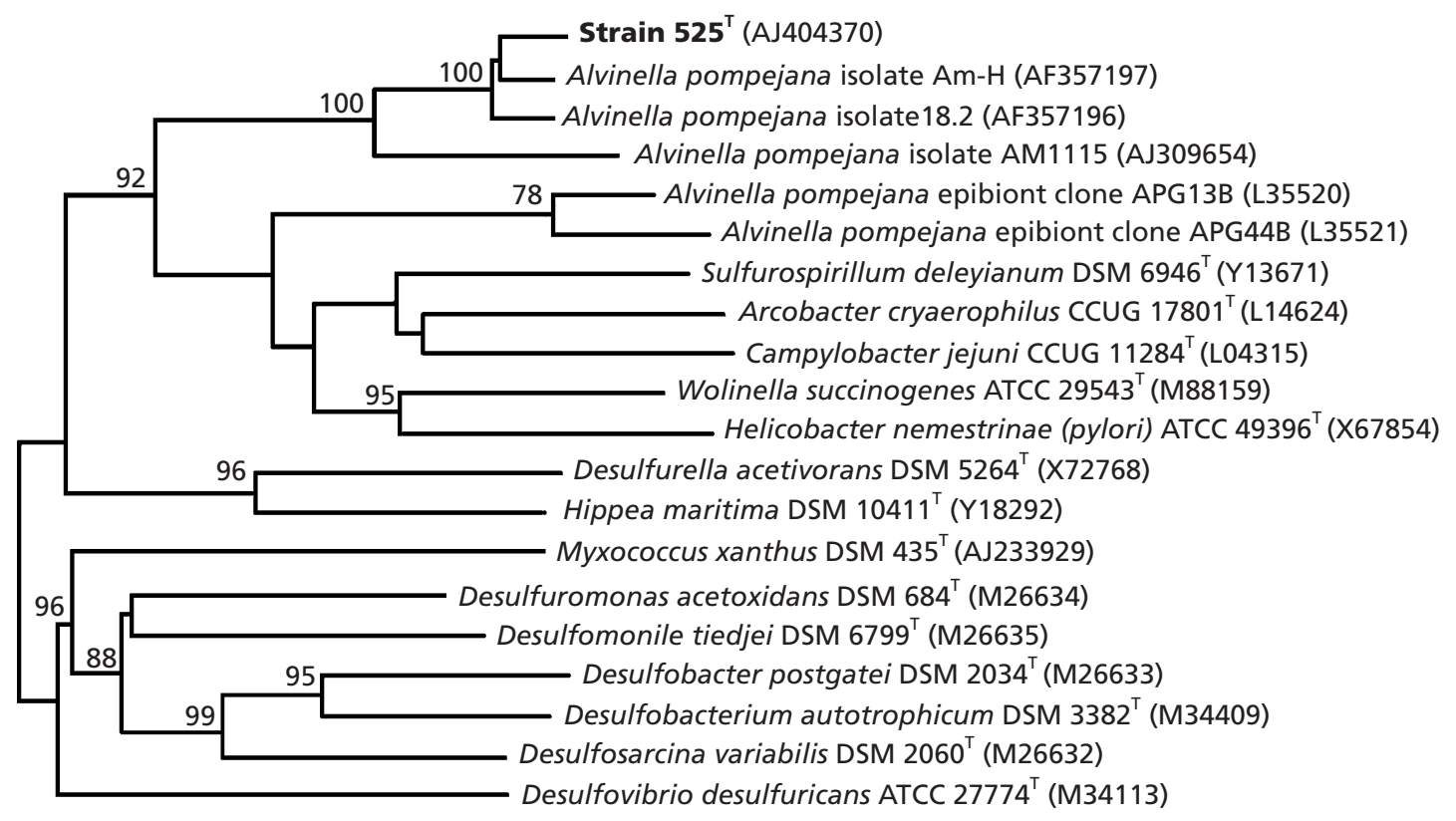

$10 \%$

Fig. 2. Phylogenetic position of strain $525^{\top}$, as derived by comparative $16 \mathrm{~S}$ rDNA analyses using the neighbour-joining algorithm (Felsenstein, 1993). The bar indicates $10 \%$ sequence divergence. Numbers at branching points refer to bootstrap values (only those values greater than $75 \%$ are shown).

was observed, among them cocci and long and short motile rods. Growth was accompanied by the production of large amounts of $\mathrm{H}_{2} \mathrm{~S}$ (up to $25 \mathrm{mM}$ ). Cultures were diluted and transferred into a formatecontaining medium solidified with agar. After 5 days incubation at $55^{\circ} \mathrm{C}$, single colonies were visible in the tubes inoculated with the highest dilutions. Colonies were round, milk-white and $0.5-1 \mathrm{~mm}$ in diameter. When cultures were transferred into mineral medium without yeast extract, the growth of short, extremely motile rods was observed after 2-3 days cultivation. The purification procedure was repeated twice. The purity of the culture was checked microscopically and by the absence of growth in a non-selective glucoseand peptone-containing medium (each $0.3 \%$ ). The pure strain designated strain $525^{\mathrm{T}}$ was studied in detail.

\section{Morphology and ultrastructure of the new isolate}

The cells of strain $525^{\mathrm{T}}$ were short rods $(0 \cdot 4-0 \cdot 75 \mu \mathrm{m}$ wide $\times 1 \cdot 1-2 \cdot 0 \mu \mathrm{m}$ long), motile by means of single polar flagellum (Fig. 1a). The formation of spores was never observed. The shape of cells varied from almost round to rod-like, sometimes with empty spaces at the ends. At the stationary phase of growth, giant cells (three times longer than usual) were observed. Thin sectioning revealed the Gram-negative structure of the cell wall (Fig. 1b, c).

\section{Growth characteristics}

Strain $525^{\mathrm{T}}$ is an obligately anaerobic micro-organism. No growth was observed in aerated medium and in the medium containing low levels of oxygen. Growth was observed in the temperature range $37-68^{\circ} \mathrm{C}$, the optimum being around $53{ }^{\circ} \mathrm{C}$. The $\mathrm{pH}$ range for growth was $6 \cdot 4-7 \cdot 4$, the optimum being $6 \cdot 8-7 \cdot 0$. The optimal $\mathrm{NaCl}$ concentration for growth was 3.0\% $(\mathrm{w} / \mathrm{v})$; no growth was observed below $0.8 \% \mathrm{NaCl}$ or above $5.0 \% \mathrm{NaCl}$ in the medium. Under optimal conditions $\left(53{ }^{\circ} \mathrm{C}, \mathrm{pH} 6.8,3 \% \mathrm{NaCl}\right)$, the doubling time of strain $525^{\mathrm{T}}$ on the medium with formate and elemental sulfur was $140 \mathrm{~min}$.

Strain $525^{\mathrm{T}}$ grew on molecular hydrogen or sodium formate as energy sources with elemental sulfur as electron acceptor. The only products detected during the growth on both substrates were $\mathrm{H}_{2} \mathrm{~S}$ and $\mathrm{CO}_{2}$. Acetate, butyrate, propionate, methanol, ethanol, pyruvate, lactate, fumarate, malate, succinate, monomethylamine, glucose, sucrose, starch, peptone and yeast extract did not support growth in the presence or the absence of elemental sulfur. Weak and slow growth was obtained when sulfite and colloidal sulfur (SigmaAldrich Chimie) were tested as electron acceptors. Strain $525^{\mathrm{T}}$ did not grow when other possible electron acceptors like sulfate, thiosulfate, nitrate, malate and ferric iron were provided.

To examine possible carbon sources other than $\mathrm{CO}_{2}$, acetate, pyruvate, formate, methylamine, methanol and malate were tested. None of them, except formate, supported growth of strain $525^{\mathrm{T}}$.

$\mathrm{NH}_{4} \mathrm{Cl}$ as a nitrogen source could be substituted by $\mathrm{NaNO}_{3}$, glutamate, yeast extract, gelatin, tryptone 
and urea. Significant growth was observed with $\mathrm{NH}_{4} \mathrm{Cl}$, urea, tryptone and yeast extract. Growth was lower and slower with glutamate and nitrate.

Strain $525^{\mathrm{T}}$ was sensitive to rifampicin $\left(50 \mu \mathrm{g} \mathrm{ml}^{-1}\right)$, chloramphenicol $\left(25 \mu \mathrm{g} \mathrm{ml}^{-1}\right)$, vancomycin, penicillin $\left(10 \mu \mathrm{g} \mathrm{ml}^{-1}\right)$ and streptomycin $\left(100 \mu \mathrm{g} \mathrm{ml}^{-1}\right)$.

\section{DNA base composition}

The $\mathrm{G}+\mathrm{C}$ content of strain $525^{\mathrm{T}}$ was $34.7 \mathrm{~mol} \%$, as determined by the HPLC method.

\section{Phylogenetic analysis}

Comparison of the almost complete 16S rDNA sequence of strain $525^{\mathrm{T}}$ against the database indicated membership of the $\varepsilon$-Proteobacteria. The highest similarity values $(90 \cdot 4-96 \cdot 7 \%)$ were found with sequences of recently isolated organisms associated with the Alvinella microbial community and hydrothermal chimneys (Campbell et al., 2001). Phylogenetic analyses showed that these sequences formed a monophyletic unit whose internal branches were supported by bootstrap analysis (Fig. 2). The lowest similarity values $(83 \cdot 7-85 \cdot 4 \%)$ were shared with Hippea maritima and Desulfurella strains, a lineage branching intermediate to the $\varepsilon$ - and $\delta$-subclasses of the Proteobacteria but which has not yet received the status of a subclass. Similarity values among strain $525^{\mathrm{T}}$ and other members of the $\varepsilon$-subclass, e.g. Sulfospirillum, Campylobacter and related taxa and the as yet uncultured strains from the hydrothermal vent polychaete A. pompejana (Haddad et al., 1995), ranged between $81 \cdot 3$ and $83.5 \%$.

\section{DISCUSSION}

Dissimilatory sulfur reduction has been shown to be one of the major catabolic reactions in hyperthermophilic archaea and was found in representatives of numerous taxa isolated from terrestrial, shallowwater and deep-sea hydrothermal habitats (Stetter, 1996; Huber et al., 2000a). The metabolic capacity is also shared by some thermophilic bacteria from terrestrial and shallow-water submarine hot vents (Bonch-Osmolovskaya, 1994) that encompass several phylogenetic lineages. Among them, representatives of the genera Desulfurella (Bonch-Osmolovskaya et al., 1990; Miroshnichenko et al., 1994, 1998) and Hippea (Miroshnichenko et al., 1999) do not belong to any of the known subclasses of the Proteobacteria (Rainey et al., 1993) and form independent branches.

In this study, we report the isolation and characterization of a novel, chemolithotrophic sulfur-reducing organism from deep-sea hydrothermal vents. Numerous thermophilic, strictly lithoautotrophic prokaryotes have been isolated from this extreme environment (Prieur et al., 1995). Most of them are hyperthermophilic archaea such as methanogens of the genera Methanopyrus (Kurr et al., 1991) and
Methanococcus (Jones et al., 1983, 1989; Jeanthon et al., 1998, 1999a, b; Zhao et al., 1988), hydrogenoxidizers of the genus Pyrolobus (Blöchl et al., 1997) and sulfur-reducers of the genus Ignicoccus (Huber et $a l ., 2000 b)$. In the domain Bacteria, extremely thermophilic sulfur-reducing representatives of Desulfurobacterium thermolithotrophum (L'Haridon et al., 1998; L'Haridon \& Jeanthon, 2001) and the recently described sulfate-reducer Thermodesulfobacterium hydrogeniphilum (Jeanthon et al., 2002) complete the list of strictly thermophilic lithotrophs thriving at deep-sea vents.

Isolate $525^{\mathrm{T}}$ described here is a strictly anaerobic thermophilic bacterium capable of chemolithoautotrophic growth with molecular hydrogen and elemental sulfur. Alternatively, this organism uses formate as electron donor and carbon source. Analysis of the $16 \mathrm{~S}$ rDNA of the new organism revealed that it belongs to the $\varepsilon$-subclass of the Proteobacteria and that its closest phylogenetic relatives are strains recently isolated from deep-sea hydrothermal vents but not yet formally described (Campbell et al., 2001). Strain $525^{\mathrm{T}}$ shares some characteristics with strain Am-H, its closest phylogenetic relative (which was roughly characterized), but also exhibits significant physiological differences. In contrast to strain $\mathrm{Am}-\mathrm{H}$, strain $525^{\mathrm{T}}$ is unable to use pyruvate as a carbon source and electron donor. Moreover, its maximum and optimum growth temperature are 13 and $8^{\circ} \mathrm{C}$ higher than those of strain Am-H, respectively. It is evident from the degree of $16 \mathrm{~S}$ rDNA similarity between strain $525^{\mathrm{T}}$ and any of the reference strains represented in the $16 \mathrm{~S}$ rDNA databases that this strain represents a novel species and a novel genus. The decision to describe a higher taxon should await complete analysis of additional members of this new lineage. On the basis of $16 \mathrm{~S}$ rDNA analysis and phenotypic differences with respect to its closest phylogenetic relatives, we propose to classify strain $525^{\mathrm{T}}$ as Nautilia lithotrophica gen. nov., sp. nov.

Assessment of the microbial diversity, using molecular methods, revealed that $\varepsilon$-Proteobacteria dominate in various deep-sea hydrothermal habitats such as the microbial mats of Loihi Seamount (Moyer et al., 1995), the surfaces of the invertebrates (Haddad et al., 1995; Polz \& Cavanaugh, 1995; Cary et al., 1997) and sulfides from the Mid-Atlantic Ridge (Reysenbach et al., 2000) and the South-East Pacific Rise (Longnecker \& Reysenbach, 2001). Unexpectedly, our study revealed that some of the $\varepsilon$-Proteobacteria detected by molecular methods display a thermophilic way of life, a physiological trait unknown, to date, among members of this subclass.

\section{Description of Nautilia gen. nov.}

Nautilia (Nau.ti'li.a. N.L. fem. n. Nautilia from Nautile, the name of the French submersible used for the exploration and investigation of deep-sea hydrothermal areas). 
Cells are short, very motile rods with single polar flagella. Cell wall is of the Gram-negative type. Obligate anaerobe. Moderate thermophile. Neutrophile. Requires $\mathrm{NaCl}$ for growth. Grows chemolithoautotrophically on molecular hydrogen, elemental sulfur and $\mathrm{CO}_{2}$. Does not utilize sugars, peptides, organic acids or alcohols both in the absence and presence of sulfur. Weakly uses sulfite and colloidal sulfur as electron acceptors; sulfate, thiosulfate, nitrate, fumarate and ferric iron are not used. The type species is Nautilia lithotrophica.

\section{Description of Nautilia lithotrophica sp. nov.}

Nautilia lithotrophica (li.tho.tro'phi.ca. Gr. masc. n. lithos stone; Gr. masc. n. trophos consuming; Gr. fem. adj. lithotrophica inorganic-substrate-consuming).

Cells are short, motile rods with single polar flagella, $0.4-0.75 \times 1.1-2.0 \mu \mathrm{m}$ in size and have the Gramnegative type of cell wall. On solid medium white colonies are formed. Obligate anaerobe. Moderate thermophile growing in the range $37-68{ }^{\circ} \mathrm{C}$, the optimum being $53{ }^{\circ} \mathrm{C}$. Neutrophile growing in the $\mathrm{pH}$ range $6 \cdot 4-7 \cdot 4$, the optimum being $\mathrm{pH} 6 \cdot 8-7 \cdot 0$. Grows at $\mathrm{NaCl}$ concentrations from 0.8 to $5.0 \%(\mathrm{w} / \mathrm{v})$, the optimum concentration being $3.0 \%$. Utilizes $\mathrm{H}_{2}$ or formate as energy source, elemental sulfur as electron acceptor and $\mathrm{CO}_{2}$ as carbon source. Sugars, peptides, organic acids and alcohols do not support growth, either in the absence or presence of elemental sulfur. Does not utilize sulfate, thiosulfate, nitrate, fumarate and ferric iron as electron acceptors, but uses sulfite and colloidal sulfur weakly. Uses only $\mathrm{CO}_{2}$ and formate, but not acetate, pyruvate, methylamine, methanol or malate as carbon sources. Uses $\mathrm{NH}_{4} \mathrm{Cl}$, $\mathrm{NaNO}_{3}$, glutamate, yeast extract, gelatin, tryptone and urea as nitrogen sources. Sensitive to rifampicin, chloramphenicol, vancomycin, penicillin and streptomycin. The $\mathrm{G}+\mathrm{C}$ content of the DNA is $34.7 \mathrm{~mol} \%$. Isolated from tube fragments of an $A$. pompejana specimen from the $13^{\circ} \mathrm{N}$ deep-sea hydrothermal vent site on the East Pacific Rise. The type strain is Nautilia lithotrophica $525^{\mathrm{T}}\left(=\mathrm{DSM} 13520^{\mathrm{T}}\right)$.

\section{ACKNOWLEDGEMENTS}

We thank the crew of the R/V L'Atalante and the pilots of the DSV Nautile for their skill during the Amistad cruise organized by the CNRS and Ifremer (in 1999). This work was supported by grants from INTAS (no. 99-1250) the Russian Foundation for Basic Research (no. 00-04-48924), the Biodiversity Programme of the Russian Ministry for Industry, Science and Technology, the Programme National Dorsales, and CNRS/Rhône-Poulenc.

\section{REFERENCES}

Balch, W. E., Fox, G. E., Magrum, G. E., Woese, G. E. \& Wolfe, R. S. (1979). Methanogens: re-evaluation of a unique biological group. Microbiol Rev 43, 260-296.

Blöchl, E., Rachel, R., Burggraf, S., Hafenbradl, D., Jannasch, H. W. \& Stetter, K. O. (1997). Pyrolobus fumarii, gen. and sp. nov., represents a novel group of archaea, extending the upper temperature limit for life to $113^{\circ} \mathrm{C}$. Extremophiles 1, 14-21.

Bonch-Osmolovskaya, E. A. (1994). Bacterial sulfur reduction in hot vents. FEMS Microbiol Rev 15, 65-77.

Bonch-Osmolovskaya, E. A., Sokolova, T. G., Kostrikina, N. A. \& Zavarzin, G. A. (1990). Desulfurella acetivorans gen. nov., sp. nov. - a new thermophilic sulfur-reducing eubacterium. Arch Microbiol 153, 151-155.

Campbell, B. J., Jeanthon, C., Kostka, J. E., Luther, G. W., III \& Cary, S. C. (2001). Growth and phylogenetic properties of novel bacteria belonging to the epsilon subdivision of the Proteobacteria enriched from Alvinella pompejana and deep-sea hydrothermal vents. Appl Environ Microbiol 67, 4566-4572.

Cary, S. C., Cottrell, M. T., Stein, J. L., Camacho, F. \& Desbruyères, D. (1997). Molecular identification and localization of filamentous symbiotic bacteria associated with the hydrothermal vent annelid Alvinella pompejana. Appl Environ Microbiol 63, 1124-1130.

De Soete, G. (1983). A least squares algorithm for fitting additive trees to proximity data. Psychometrika 48, 621-626.

Felsenstein, J. (1993). PHYLIP (Phylogeny Inference Package) version 3.5.1. Seattle: Department of Genetics, University of Washington.

Haddad, A., Camacho, F., Durand, P. \& Cary, S. C. (1995). Phylogenetic characterization of the epibiotic bacteria associated with the hydrothermal vent polychaete Alvinella pompejana. Appl Environ Microbiol 61, 1679-1687.

Huber, R., Huber, H. \& Stetter, K. O. (2000a). Towards the ecology of hyperthermophiles: biotopes, new isolation strategies and novel metabolic properties. FEMS Microbiol Rev 24, 615-623.

Huber, H., Burggraf, S., Mayer, T., Wyschkony, I., Rachel, R. \& Stetter, K. O. (2000 b). Ignicoccus gen. nov., a novel genus of hyperthermophilic, chemolithoautotrophic Archaea, represented by two new species, Ignicoccus islandicus sp. nov. and Ignicoccus pacificus sp. nov. Int J Syst Evol Microbiol 50, 2093-2100.

Jannasch, H. W. \& Mottl, M. J. (1985). Geomicrobiology of deep-sea hydrothermal vents. Science 229, 717-726.

Jeanthon, C., L'Haridon, S., Reysenbach, A.-L., Vernet, M., Messner, P., Sleytr, U. W. \& Prieur, D. (1998). Methanococcus infernus sp. nov., a novel hyperthermophilic lithotrophic methanogen isolated from a deep-sea hydrothermal vent. Int J Syst Bacteriol 48, 913-919.

Jeanthon, C., L'Haridon, S., Pradel, N. \& Prieur, D. (1999a). Rapid identification of hyperthermophilic methanococci isolated from deepsea hydrothermal vents. Int J Syst Bacteriol 49, 591-594.

Jeanthon, C., L'Haridon, S., Reysenbach, A.-L., Corre, E., Vernet, M., Messner, P., Sleytr, U. W. \& Prieur, D. (1999b). Methanococcus vulcanius sp. nov., a novel hyperthermophilic methanogen isolated from East Pacific Rise and identification of Methanococcus sp. DSM 4213 as Methanococcus fervens sp. nov. Int J Syst Bacteriol 49, 583-589.

Jeanthon, C., L'Haridon, S., Cueff, V., Banta, A., Reysenbach, A.-L. \& Prieur, D. (2002). Thermodesulfobacterium hydrogeniphilum sp. nov., a thermophilic, chemolithoautotrophic, sulfate-reducing bacterium isolated from a deep-sea hydrothermal vent at Guaymas Basin, and emendation of the genus Thermodesulfobacterium. Int $J$ Syst Evol Microbiol 52, 765-772.

Jones, W. J., Leigh, J. A., Mayer, F., Woese, C. R. \& Wolfe, R. S. (1983). Methanococcus jannaschii sp. nov., an extremely thermophilic methanogen from a submarine hot vent. Arch Microbiol 136, 254-261.

Jones, W. J., Stugard, C. E. \& Jannasch, H. W. (1989). Comparison of thermophilic methanogens from submarine hot vents. Arch Microbiol 151, 214-318.

Jukes, T. H. \& Cantor, C. R. (1969). Evolution of protein molecules. In Mammalian Protein Metabolism, pp. 21-132. Edited by H. N. Munro. New York: Academic Press.

Kurr, M., Huber, R., Koenig, H., Jannasch, H. W., Fricke, H., Trincone, A., Kristjansson, J. K. \& Stetter, K. O. (1991). Methanopyrus kandleri, gen. and sp. nov. represents a novel group of hyperthermopholic methanogens, growing at $110^{\circ} \mathrm{C}$. Arch Microbiol 156, 239-247. 
Labrenz, M., Tindall, B. J., Lawson, P. A., Collins, M. D., Schumann, P. \& Hirsch, P. (2000). Staleya guttiformis gen. nov., sp. nov. and Sulfitobacter brevis sp. nov., $\alpha$-3-Proteobacteria from hypersaline, heliothermal and meromictic antarctic Ekho Lake. Int J Syst Evol Microbiol 50, 303-313.

L'Haridon, S. \& Jeanthon, C. (2001). Genus Desulfurobacterium. In Bergey's Manual of Systematic Bacteriology: the Archaea, Cyanobacteria, Phototrophs and Deeply Branching Bacteria, 2nd edn, pp. 356-357. Edited by G. M. Garrity. New York: Springer.

L'Haridon, S., Cilia, V., Messner, P., Raguenes, G., Gambacorta, A., Sleytr, U. B., Prieur, D. \& Jeanthon, C. (1998). Desulfurobacterium thermolithotrophum gen. nov., sp. nov., a novel autotrophic, sulfurreducing bacterium isolated from a deep-sea hydrothermal vent. Int $J$ Syst Bacteriol 48, 701-711.

Longnecker, K. \& Reysenbach, A.-L. (2001). Expansion of geographic distribution of a novel lineage of $\varepsilon$-Proteobacteria to a hydrothermal vent site on the Southern East Pacific Rise. FEMS Microbiol Ecol 35, 13-38.

Maidak, B. L., Olsen, G. J., Larsen, N., Overbeek, R., McCaughey, M. J. \& Woese, C. R. (1996). The Ribosomal Database Project (RDP). Nucleic Acids Res 24, 82-85.

Mesbah, M., Premachandran, U. \& Whitman, W. B. (1989). Precise measurement of the $\mathrm{G}+\mathrm{C}$ content of deoxyribonucleic acid by highperformance liquid chromatography. Int J Syst Bacteriol 39, 159-167.

Miroshnichenko, M. L., Gongadze, G. M., Lysenko, A. M. \& BonchOsmolovskaya, E. A. (1994). Desulfurella multipotens sp. nov., a new sulfur-respiring thermophilic eubacterium from Raoul Island (Kermadec archipelago). Arch Microbiol 161, 88-93.

Miroshnichenko, M. L., Rainey, F. A., Hippe, H., Chernyh, N. A., Kostrikina, N. A. \& Bonch-Osmolovskaya, E. A. (1998). Desulfurella kamchatkiensis sp. nov. and Desulfurella propionica sp. nov. - sulfurrespiring thermophilic bacteria from Kamchatka thermal environments. Int J Syst Bacteriol 48, 475-479.

Miroshnichenko, M. L., Rainey, F. A., Rhode, M. \& Bonch-Osmolovskaya, E. A. (1999). Hippea maritima gen. nov., sp. nov., a new genus of thermophilic, sulfur-reducing bacterium from submarine hot vents. Int J Syst Bacteriol 49, 1033-1038.
Moyer, C. L., Dobb, F. C. \& Karl, D. M. (1995). Phylogenetic diversity of the bacterial community from a microbial mat at an active, hydrothermal vent system. Appl Environ Microbiol 61, 1555-1562.

Polz, M. F. \& Cavanaugh, C. M. (1995). Dominance of one bacterial phylotype at a Mid-Atlantic Ridge hydrothermal vent site. Proc Natl Acad Sci U S A 92, 7232-7236.

Prieur, D., Jeanthon, C. \& Erauso, G. (1995). Hyperthermophilic life at deep-sea hydrothermal vents. Planet Space Sci 43, 115-122.

Rainey, F. A., Toalster, R. \& Stackebrandt, E. (1993). Desulfurella acetivorans, a thermophilic, acetate-oxidizing and sulfur-reducing organism, represents a distinct lineage within the Proteobacteria. Syst Appl Microbiol 16, 373-379.

Rainey, F. A., Ward-Rainey, N., Kroppenstedt, R. M. \& Stackebrandt, E. (1996). The genus Nocardiopsis represents a phylogenetically coherent taxon and a distinct actinomycete lineage: proposal of Nocardiopsaceae fam. nov. Int J Syst Bacteriol 46, 1088-1092.

Reysenbach, A.-L., Longnecker, K. \& Kirshtein, J. (2000). Novel bacterial and archaeal lineages from an in situ growth chamber deployed at a Mid-Atlantic Ridge hydrothermal vent. Appl Environ Microbiol 66, 3788-3797.

Stetter, K. O. (1996). Hyperthermophilic procaryotes. FEMS Microbiol Rev 18, 149-158.

Trüper, H. G. \& Schlegel, H. G. (1964). Sulfur metabolism in Thiorhodaceae. I. Quantitative measurements on growing cells of Chromatium okenii. Antonie Leeuwenhoek J Microbiol Serol 30, 225-232.

Widdel, F. \& Pfennig, N. (1992). The genus Desulfuromonas and other gram-negative sulfur-reducing eubacteria. In The Prokaryotes, 2nd edn, vol. 1, pp. 3379-3389. Edited by A. Balows, H. G. Trüper, M. Dworkin, W. Harder \& K. H. Schleifer. New York: Springer.

Wolin, E. A., Wolin, M. J. \& Wolfe, R. S. (1963). Formation of methane by bacterial extracts. $J$ Biol Chem 238, 2882-2888.

Zhao, H., Wood, A. G., Widdel, F. \& Bryant, M. P. (1988). An extremely thermophilic Methanococcus from a deep-sea hydrothermal vent and its plasmid. Arch Microbiol 150, 178-183. 